\section{Przegląd Badań Edukacyjnych Educational Studies Review}

ISSN 1895-4308

nr 29 (2/2019), s. 209-235

Angelika Cieślikowska-Ryczko

ORCID: 0000-0002-5270-2739

University of Lodz; e-mail: angelika.cieslikowska@uni.lodz.pl

Gabriela Dobińska

ORCID: 0000-0003-3629-5210

University of Lodz; e-mail: gabriela.dobinska@uni.lodz.pl
METODY ZBIERANIA

I ANALIZY DANYCH

W BADANIACH

EDUKACYJNYCH

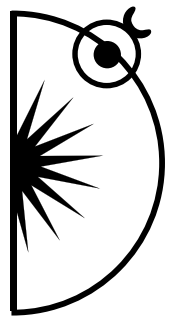

\title{
Using the Photographic Walk Technique in the Field Work of Probation Officers
}

http://dx.doi.org/10.12775/PBE.2019.024

\begin{abstract}
Using the potential of the photographic walk the authors studied the organization of field work of probation officers. The main area of interest is the manner of perceiving, naming, familiarizing oneself with places, and place making by the respondents. The aim of the study is to 1) verify the usefulness (potential) of the photographic walk method in the suggested project and 2) describe the field work organization of probation officers, based on collected data. In the article we reached two key conclusions, encompassing 1) the perception and description of field work conducted "in progress," and the connection between the physical space of the city and the professional work of probation officers, and 2) subjective, emotional and transcendental perception, including ascribing symbolic meanings to "the route" traversed in the course of work.
\end{abstract}

Key words: visual methods, mobile methods, investigative/exploratory walk, photography in social studies, mobility and place, field work of probation officers 


\section{Probation Officers in a Legal and Pedagogical Context}

The issue of legal guardianship is often the subject of interest in social studies. Despite numerous research papers there are constantly new analyses, the aim of which is to learn the multi-context character of the work of probation officers. A review of selected analyses from the previous decade reveals that this issue is explored in relation to the effectiveness of the activities, the suggested systematic solutions, and the quality of interactions between probation officers and their wards (see also Cywiński, 2018; Jedynak, Stasiak, 2014; Górnicka, 2016; Hsieh, Hofoka, Woo, Wormer, Stohr, Hemmens, 2017; Viglione, Rudes, Taxman, 2017). The issues most frequently taken up in Polish studies are solutions concerning occupational obligations, resulting from the applied punitive or didactic measures (see also Jadach, 2011; Bałandynowicz, 2007; Stasiak, 2010; Gogacz, 2012), the dangers related to the profession of probation officer (see also Wojtera, 2012; Janus-Dębska, Gronkiewicz-Ostaszewska, 2016), their professional competences (see also Węgliński, 2015; Nowak, 2009/2010), and sources of stress resulting from their functions (see also Skowroński, 2016; Wirkus, 2015). The above studies are part of probation, understood as a social project implemented in an open environment. The functions of probation consist in custody, control and social change through complementary informal and formal (professional) support (see also Bałandynowicz, 2007; Gawęcka, 2009).

The everyday reality among representatives of the judicial service is grounded in the legal system, which determines the conditions of work organization and the character of professional activities, through acts and regulations. In the legal dimension the fundamental document which regulates the status of the probation judicial service is the Probation Officer Act of 27 July 2001 (Journal of Laws from 2001, No. 98, item 1071), which determines the scope of tasks, duties, as well as regulations concerning promotions, salaries, and rules regarding application. General regulations define probation officers as people who carry out specified tasks connected with diagnosis, control, education, rehabilitation and prevention (Art. 1, Journal of Laws from 2001, No. 98, item 1071). In the eyes of the law we are dealing with a division in legal guardianship, with regard to specification of fulfilled duties and organizational issues ${ }^{1}$.

${ }^{1}$ Due to the scope of activities under Polish law we distinguish professional and social probation officers. The latter work on behalf of society, and thus are not expected to take part in the application process or to have professional training. Professional probation officers, having passed their exams, fulfill the role of public officials and are bound by an employment relationship. Apart 
An analysis of legal acts reveals differences in the specification of the scope of duties between adult and family probation officers. Despite common areas there are clear differences in their professional competences. Family probation officers focus on pedagogical measures, whereas adult probation officers justify their decisions on the grounds of control and supervision. The work of probation officers is often centred around people functioning in dysfunctional, poor or criminal environments, often afflicted with a multigenerational mechanism of reproducing undesired socio-cultural patterns (Marynowicz-Hetka, 2010, p. 16). The prevention of such a state of affairs requires efficient orientation, as well as a high level of professional competence. Performing the tasks of probation officer, and thereby the effectiveness of rehabilitation measures, are determined by an adequate application of educational measures, the quality of cooperation with wards, and organisational competence in the context of coping with work in two different environments, i.e. the court and the field (see also Nowak, 2009, 2010). Moreover, the work of probation officers is heavily bureaucratised and determined by legal and formal rules. In the regulation on the detailed method of exercising powers and duties of probation officers (Journal of Laws from 2003, No. 112, item 1064) the legislator repeatedly indicates responsibilities connected with becoming familiar with files related to the case, making notes, conducting community interviews, drawing up assessments, as well as numerous reporting activities.

Another important feature characterising the specificity of work in legal guardianship are irregular working hours, which means that the probation officer has to organise their everyday responsibilities by themselves. The work of probation officers is not routine, predictable or repetitive. Moreover, the daily work routine takes place on two parallel planes - the court (institution) and the field (areas within the city). They perform their work in particularly difficult conditions, in the environment of their wards - people whose behaviour is inconsistent with established social and legal norms. We are dealing with a dichotomy of the profession. On the one hand, probation officers experience strong formalisation in their work (i.e. difficult and legally complicated interactions, assets and measures), on the other hand, the quality of their work

from the fundamental legislation act (Probation Officer Act of 27 July 2001) determining the work structure of probation officers, there is also the Regulation of the Minister of Justice of 26 February 2013, on the method of exercising powers and duties probation officers in criminal enforcement cases (Journal of Laws from 2013, item 335), and the Regulation of the Minister of Justice of 12 June 2003, on the detailed method of exercising powers and duties of probation officers (Journal of Laws 2003, No. 112, item 1064). 
largely depends on personal traits, the ability to create constructive interpersonal relationships in planning supportive action (see also Nowak, 2009, 2010, p. 291-299; Heine 2008, p. 120-128).

Field work, in its broad sense, is burdened with particular difficulties and dangers. It is worth paying attention to the specific character of work in this area, in which the probation officer as the "alien" representative of the justice system enters the comfort zone of their wards (by visiting districts, flats, streets, types of social and spatial communities, becoming a guest, supervisor or guardian). The probation officer performs their duties in unpredictable and often life or health-threatening conditions. While performing their duties a probation officer exposes themselves to hostile (aggressive) reactions from the wards, their family members, people in the immediate environment, as well as animals (e.g. being bitten by dogs) (Wojtera, 2012, p. 187-189). In his studies on social representations of members of probation interactions Aleksander Cywiński (2018, p. 172-175; 283-290) also indicates the sense of security among probation officers conducting field work (an environment isolated from institutional security guarantees). It is interesting to note that a sense of threat coming from the wards was supplanted by fear generated by difficult and neglected urban areas. According to the author, the field dimension of the work of probation officers allows one to balance between two separate worlds: the 'normies' and the criminals. The second one, perceived as dangerous and inaccessible to ordinary people, opens up to probation officers in a peculiar manner. One can assume that the work area is a particularly important aspect of social representation, and therefore a part of the creation of one's professional identity. Probation officers who enter an unknown area associated by locals with crime, poverty and demoralization subdue its physical aspect, making it less "wild and dangerous." The field dimension of the profession is an inseparable aspect of professional activities. Cywiński (2018, p. 290-295), who notices the relationship between the field and the institutional character of the work, distinguishes court-oriented officers, referring to the as KOS, and field-oriented officers, whom he calls KOT (eng. cat). Both groups define and apply their measures in a specific manner. Officers whose working time is determined by the institution - according to Cywiński - are meticulous in their administrative tasks, work unilaterally according to procedures and legal step plans, avoiding dilemmas regarding decision making. A KOT officer understands his/her job differently. While spending time in the field he/she gets to know his/her wards, familiarises space, and treats his/her wards as subjects. Taking into account the fluidity and changeability of social conditions the KOT tries to establish emancipatory relations with their 
wards, unlike the KOS (eng. blackbird), who designs their work based on strictly formalised procedures, perceiving the ward as an object. Thus, a probation officer who performs his/her duties in the field interacts with the space and with the wards, which significantly impacts his/her identity (not only professional). The stream of these interactions may determine the quality of an officer's responsibilities, perception, a way of defining and interpreting the city. Active participation in dynamic urban space enables one to subjectively experience the agglomeration, by attributing individualised meanings, significance and symbols (cf. Majer, 2015 p. 24-32). Personal experience of the city and space, attributing meaning to particular elements along the officer's route, characterising significant points, familiarising non-places and placing oneself within the urban structures, which are located between formalised institutional space and the private home of the ward, are of key significance for the discussed research project.

\section{Visual Studies in Social Science}

The birth of sociology as a scientific discipline and of photography as a technological achievement coincided in 1893, when August Comte published his Cours de philosophie positive and Louise Jacques Daguerre presented his innovative technique of capturing images before the French Academy of Sciences. Scientists, researchers, artists and 'ordinary' recipients of visual arts have long wondered what is, what is the purpose of and how to read the photographic record. For some a photograph is a document - a tool which allows one to faithfully recapture what is "seen" (a reflection of reality). Others perceive a photograph as text or a cultural expression, which requires not only a superficial reading, but also a thorough and multidimensional interpretation (subject to the process of attributing symbolic meanings). Despite the passage of time the dilemma has not been resolved (see also among others Bourdieu, 1990; Becker, 1998; Emmison, Smith, 2000; Grady, 2009). When we think of visual studies we need to emphasise that no image or visual practice is scientific in itself (it is not ethnographically or sociologically significant). The nature of photographs can be twofold: personal (e.g. as mementos in private albums) or exploratory, when they undergo analysis which entails methodological directives. However, this division does not set impassable boundaries. Using adequate arguments researchers can expropriate personal photographs for exploratory purposes and the other way around - an exploratory work may become a sentimental personal photograph. According to Sarah Pink (2007, p. 89) there are no clear guidelines 
which allow one to determine whether a given photograph is ethnographic (important from the point of view of social studies) or personal.

The application and flourishing of sociology with the use of photography dates back to the beginning of the $20^{\text {th }}$ century ${ }^{2}$. Howard Becker is regarded as the pioneer of visual studies (1974 article titled: "Photography and sociology," published in "Studies in the Anthropology of Visual Communication"). Despite the passage of time contemporary visual researchers face similar dilemmas to those described by Becker: Do photographs tell the truth? Can photographs, as reflections of the researcher's personal perspective, show scientific objectivism? How to make a sociological photograph (one that would be scientifically relevant)? Becker stresses that in photography for research purposes one needs to avoid accumulating unrelated photos, and instead produce sociological images of "sequence of events," which will allow the dynamic aspects of social organization to be recreated. However, even such an implementation of the procedure does not guarantee a "scientific character" of the photograph (see. Becker 1974, 1979).

Then how do we achieve 'scientific photography'? According to John Collier and Malcolm Collier (1986, p. 161-173), procedures, structures, and observed categories which can provide specific data have to be in place for a given activity to be deemed visual research. The researcher-photographer is faced with the task of creating a coherent image in form of a compressed sample of elements and events observed in time and space. As a result of these activities the researcher should be able to conduct a comparative analysis. According to Collier and Collier, a proper analysis can only be conducted on material which encompasses the entire context of the studied object, and at the same time is subject to a sequential ordering. Otherwise, even the most interesting image becomes a useless illustration (from the point of view of scientific analyses).

The comments and directives made by the Colliers are only some of many examples of attempts to make photographic documentation (photographic em-

2 Between 1989 and 2016 the "American Journal of Sociology" published 31 articles which included a total of 244 photographs. Many of these articles were connected with the Chicago housing project implemented at the time. Researchers stress that two-thirds of these articles used photographs in a way which would be questioned by modern visual sociology. This is evidenced by iconographic poses, intentional posing, portraits devoid of a broader context, incoherent images of 'before and after', etc. The photographs served as illustrations rather than research material. It is undeniable that visual research was developed based on American achievements in implementing and utilising visual methods, and that this type of research has been shaping its methodological identity for a number of years (see also Emmison, Smith, 2000). 
pirical material) scientific. Numerous dilemmas accompanying visual research contribute to the emergence of various approaches and typologies of research using photography. The course of visual studies was determined (among others) by Jon Wagner (1979), who provided characteristics of 5 types of studies using photographs, focusing on the role of photography in designing, implementing and developing analyses. He distinguished: 1) photography as a specific stimulus which initiates an interview, 2) photography perceived as a systematic collection of data (registering images of life) using cameras or video cameras, 3 ) documentary photography, which he calls the narrative visual theory, consisting in a photographic exploration of visual coefficients of social organization, 4) content analysis of "naïve" photography, which encompasses amateur and professional (i.e. not taken by the researcher) photography, and 5) an analysis of native image-taking, where the researcher equips the local community with photographic equipment and later analyses the collected material (Wagner, 1979).

A decade after Wagner Douglas Harper (1987) suggested a simpler division into two basic types of visual studies, i.e. using photography as a technique of collecting data, and studies in which visual sociologists analyse the photographic material created by culture (e.g. advertisements, family albums). In this division the author highlights the basic and extremely important distinction for researchers, into those who take photographs in order to conduct visual studies of the world, and those who focus on analysing photographs taken by others.

Nowadays we often refer to the typology created by Marcus Banks (2009), which consists of three broad categories: the first one is defined as creating visual presentations (studies of society through the creation of images), the second one is understood as studies of already existing visual presentations, i.e. a study of images in order to obtain information on the society, and the last category is based on cooperation with social actors, in order to create visual presentations (see also Banks, 2009, Pink, 2007, p. 58). A similar distinction was made by Pink (2007, p. 95), who distinguishes between: 1) photography as a method of recording visual data, 2) photography based on cooperation between respondent and researcher, and 3) interview using photography (as initiation or stimulation). According to Pink (2007, p. 95-100), neither of these methods is usually applied in isolation. On the contrary, in studies using photography one often encounters a specific triangulation of methods, researchers, and data sources, which complicates research procedures, thus decreasing chances of success, while increasing the possibilities and scope of using individual methods. 


\section{Photographic Walk at an Intersection of Mobile and Visual Methods}

Using the potential of mobile and visual methods constituted the main source of cognition in the implementation of the authors' studies. Mobile methods, to put it simply, are methods based on obtaining empirical data during movement. An exploratory walk which uses this mobility is a type of interaction between a researcher and a respondent "along the way." While collecting empirical material the researcher experiences specific space along with the respondent, i.e. he observes, listens and moderates the conversation. Exploratory walks which take place "in motion" allow one to collect various data (speech/narratives, video image, photo, observation), which in the course of analysis are subject to comparison, and are finally "translated" into a unified description (see also Sheller, Urry, 2006). Mobile methods (exploratory walk) are used with increasing frequency in order to observe the relationship between an individual (experience, identity) and a place (space, location). Brett Lashua (2006, p. 391-410), using the interview technique while moving, investigated places important for young people living in areas subject to revitalisation. These studies showed that using mobile methods (conversation while walking/along the way) is a source of a "three-way conversation" between a respondent, a researcher, and space. In criminology research by leading visual researcher Megan O'Neill (2010, 2014a), walking and carrying out mobile interviews constitutes an integral part of perceiving the environment, and a method of learning about the experiences and identities of people at risk of social exclusion. Walking focuses on the sensual, kinaesthetic, and mobile character of the experience, and on the relationship between all senses. The exploratory walk fosters spontaneity of conversation, and establishes a specific spatial context between a researcher and a respondent (it does not force them to sit opposite each other, to look at a specific point, to construct a fixed setting or to maintain distance between the participants of the interaction, etc.), which can be conducive to conversation and narrative (see: Edensor, 2010; Myers, 2010; Pink, 2007, 2008; O'Neill, 2010; 2014a; O'Neill, Perivolaris, 2014b). What is more, the exploratory walk method, as a combination of a classic interview and observation, has the advantages of both these methods. Using this synergic combination a researcher gains greater access to reality perceived as a multisensory experience, constituting the basis of various socially-oriented activities. Mobile methods (exploratory walks) allow to explore everyday practices of movement and, at the same time, to understand inaccessible (especially using classic research methods) proces- 
ses taking place in the course of shifting from one spatial and social context into another (see also Murray, 2012). As emphasized by Leslie Murray (2012, p. 783), the fact that daily activities are strongly rooted in a specific spatial context means that conducting research in different spaces may significantly restrict the potential of the data. Consequently, a researcher is unable to become familiar with the direct relationship between the participant of the study, and the emotional and social reality surrounding them. Moreover, according to Jon Anderson (2004, p. 254), interviews conducted during movement allow access to human knowledge, which has a socio-spatial nature.

The photographic walk technique used in the study is a type of exploratory walk, which combines the assumptions concerning mobile and visual methods listed above. Photographic walk occurs in motion (during movement) and implies a simultaneous interview with obtaining photographic material. It needs to be stressed that collected photographs do not serve merely as illustrations. On the contrary, they constitute valuable empirical material, equal to the interview and observation conducted by the researcher ${ }^{3}$.

The described proposal of collecting empirical data constituted a synergic method of learning about the professional world of probation officers. Theoretical reflection on the professional space of probation officers allows to distinguish those areas of their professional activity which transcend systemic divisions. The starting point was the characterization of 3 basic professional spaces, which in practice may shape the professional identity of probation officers (see also Cywiński, 2018, among others). These are: 1) institution understood as court, in which the probation officer fulfils part of their professional responsibilities, connected most of all with formal development of reports etc., 2) outside institution space (oscillating between institutional work and work within a specific environment), i.e. prisons, educational-care and rehabilitation facilities where the wards reside, and 3 ) the most complex and diverse - the environment of the wards, constructed from minor micro-spaces rooted in an urban context, including: the wards' flats/houses, staircases and yards, schools, community centres, culture centres, social welfare centres, polyclinics, and the route which connects these dimensions, used by the probation officer in the course of their work.

3 It should be noted that the photographic walk combined with an interview is not the same as an interview using photography. The second method, though seemingly close or even the same, is based on completely different procedures and scientific assumptions. It is a type of photo-development of information, where the respondent, under the influence of a set of photographs (taken by him/her or by the researcher), is stimulated to talk. This interview may be supported by mobility, however, mobility does not constitute its basis (essence). 
It is that last space (temporal, elusive, ephemeral) which constitutes the main object of this study. The study took the form of a scientific experiment aimed at studying the experience of a probation officer, acquired while moving in urban space. At that time the mobile method of studying social reality, which enables direct access to empirical data (being "within" and "during" the characterised experiences) seemed the most adequate choice. Constructing a relationship between an individual and space (in other words, a specific interaction between a respondent and space) depends on local discourses and sensory experience lying at the base of conducting field activities (cf. O’Neill, 2010; 2014a; O'Neill, Perivolaris, 2014b).

\section{Outline of the Organisation and Course of the Study. Potentials and Risks of the Method}

The study was conducted over a period of one year. The collected empirical material includes one unstructured interview conducted in institutional space (court of law) and 8 other interviews conducted during photographic walks. The respondents were probation officers working within Polish prevention, education and care as well as rehabilitation system, whose wards were families and individuals, especially people who were conditionally discharged. The project was to consist of 3 compatible phases, requiring the involvement of two researchers.

It should be noted that conducting a classic interview with a probation officer makes one aware of the futility of engaging in such talks in the 'absence' of the main protagonist of the narrative, i.e. location/space. The statements made by probation officer in this interview are full of street names and constant attempts at visualizing the administrative space of the city (an attempt at providing a 'technical' characteristic of objects and their location, a broad description of the administrative division, drawing attention away from the object of conversation). On the other hand, the probation officer used certain mental shortcuts and local symbols, which only inhabitants of Lodz could understand, for example: you know what it's like in Baluty (Baluty is the most densely populated district of Lodz, with a high crime rate, and is considered dangerous by inhabitants) (see also Warzywoda-Kruszyńska, Jankowski, 2013). An analysis of the interview conducted by our research team highlighted 'misunderstandings' in interpretation, resulting from different backgrounds and experiences of the researchers (i.e. degree of familiarity with the city). The researcher from Lodz analysed the symbols and meanings included in the respondent's narrative 
through the lens of her own experience connected with the city as the place she had come from, contrary to the second researcher, who did not know the topography and character of the discussed space equally well. The material consisting only of narratives by the officers brought about numerous restrictions and simplifications. Most importantly, it impeded access to detailed data and the sociospatial context. Not the characteristics of the city from probation officers' point of view (elicited during the first interview) but the characteristics of field work grounded in the context of experiencing a 'personal city' was of key importance. The 'three-way conversation' achieved as a result of the photographic walk not only allowed the researchers to focus on the research objectives, but also made the results clearer for the wider public. The researchers sought answers to the following research questions: What is the course and what characterises the field work of probation officers 'during movement'? How do probation officers perceive and define their work area experiencing space 'here and now'? Do probation officers attribute symbolic meaning to visited/travelled urban spaces, and if so what are they? Is there a relationship between the physical space of the city (location) and the professional activity of probation officers? How does this relationship (between probation officer and location) 'shape' conducted professional activities and relationships with wards?

Photographic walks were carried out in the following stages:

Phase 1 (preparatory), apart from the theoretical considerations (on the work of probation officers in the space of the city of Lodz) and organisational preparations ${ }^{4}$, included preparing a list of objectives and initial thematic areas, connected with the subject of the study. On the basis of the questions the researchers developed answer cards, which were casual drafts (a 'framework' of conversation). The cards encompassed two themes - the first concerned areas 'here and now,' directly referring to the route (mutually experienced space, e.g. what we see here/tell us about this place), and the second, a more general one, which transcended direct mutual experience, and explored general subjective observations concerning the city, its development etc. (e.g. a definition of 'one's city'/a sense of aesthetics in the city/a sense of security/city of work and city of life).

Phase 2 (the proper stage of the walks), in which the respondent delineated the meeting space (choosing one district under his supervision). Two researchers participated in the walk - the moderator who recorded the conversation, and the person

${ }^{4}$ The study was carried out with the consent of the President of Circuit Court. The written consent is in the possession of the project coordinator. 
who collected visual (photographic) data. The initial question was open, and concerned 'describing the route' (tell us about one route from the court/home or other random place into the field, i.e. the place of the ward's residence. You can tell it as an adventure, a book chapter or a film script $)^{5}$. The content of the respondent's statements determined the direction of the conversation. The journey was made on foot or - depending on the distance and the officer's preference - by car. In such cases the conversation was continued during the car ride. The entire course of the journey was sequentially registered using a camera. The researcher responsible for registering images constructed three types of photographs, called respectively: the panorama (a general recording of space, a wide plan with numerous elements, depicting the context of the story), indications (i.e. objects, things, details to which part of the officer's narrative was devoted, shown directly through gestures), and specified indications, which included objects and details not indicated directly, e.g. through hand gestures, but referred to in the narrative. The officers put them in the centre of anecdotes and revealed personal attitudes towards them. The photographs were adequately marked at the moment of being taken. The concluding part of this phase was an 'analysis closing the walk,' which occurred directly after the meeting. It turned into a discussion and exchange of observations between both researchers, as well as a review of the photographs. The report was based on photographs, understood as 'visual quotations,' and on comments by the researchers. The final data collected during each individual meeting (after a final comparative analysis) include: photographic material (several dozen photographs of various types), a transcript of the interview, and a report from the 'analysis closing the walk.' Phase 3 (comparative analysis) allows to decode the visual components into verbal form (a type of translation). Three sources of data were consecutively constructed in code form, and developed within the framework of analytical categories subject to multiple discussions.

\section{Results of Own Research}

As Andrzej Majer (2016, p. 10-13) points out, people have a need to experience a permanent relationship with a fragment of 'their' domesticated space, with which they identify. The person-space relationship allows to maintain balance, security, and to work out a permanent daily rhythm. In the course of the research

${ }^{5}$ Conversation initiated in this way was inspired by the LAAF (life as a film) procedure, described by Donna Youngs, David Canter and Nikki Carthy (2014). 
the authors discovered boundaries and dimensions of this domestication, while trying to answer the following questions: how is the social and professional identity of probation officers shaped, and where is the boundary between what is inscribed into personal biography, and what constitutes an element of professional biography? While participating in the probation officers' walk from the court to the wards, the researchers had an opportunity to record the selected dimensions of the professional world in the existing social and cultural context. The researchers assumed that personal experience of the city may play an important role in the manner of conducting professional activities. On the other hand, field work impacts the dimensions of private life in the city. The process of change and creation includes both the perception of oneself (the probation officer) and of the city. The specific character of the agglomeration can be perceived through the lens of its physicality or value (see also Short, 2006). The probation officer experiences the collision of two dimensions, within which processes of evaluation and confrontation occur (constant collisions between mine and not mine, private and professional, formal and informal, close and alien, dangerous and domesticated etc.). The areas of such confrontations may manifest themselves in physical (tangible and material) or metaphorical (subjective and symbolic) structures.

\section{On Location and Space. The Physical Context in the Creation of Probation Officers' Professional Activities}

The researchers began by analysing the physical context (the visible, tangible context, related to senses - primarily sight - and the creation and perception of oneself in urban space). The specific creation of one's image and the attempts made by probation officers to achieve 'transparency' are especially interesting. Probation officers as institutional representatives (commissioners of the court) in their own way (simultaneously unhampered by any rules) physically enter the 'alien' area of their wards. Synergy of image and narrative (especially the encounter between respondent and researcher in the supervised district) showed coherence between the dynamic, urban space and the creation of one's image. Respondents seemed to select elements of their wardrobe (suitable to the requirements of the visited space) in a manner natural to themselves, and equipped themselves with attributes which facilitated various activities. Participating in the journeys of probation officers from the courts to the wards made it possible to observe the elementary tactics of the profession, i.e. equipment and manner in which particular tools/objects are handled, e.g. flashlights, comforta- 
ble shoes, neutral clothes - far from the formal court dress code, mobile apps, GPS, notebooks with addresses, names or other identifying data prepared in a way which is accessible to the officer (sometimes written in code understood only by the respondent), clean paper or mobile phones.

N4: I usually dress in a sporty manner, and there's no difference, whether I go to court in a jacket and tie or in such a casual manner. I don't have any special field clothes for private purposes. Although sometimes we do go to places where its challenging and you don't know how to act.

It is worth highlighting the inter-penetration expressed in the creation of one's own image of what is formalised (related to court), and what belongs to the field, with privacy. The above fragment clearly stresses the character of the city as an area of intersection and confrontation of three planes of functioning two professional and one personal. By showing one of the aspects of everyday activity the probation officer simultaneously reveals the secrets of the social world (the world of life, the professional world).

It should be noted that among the attributes one could clearly see the duality of the profession's character - on the one hand objects belonging to a 'traveler' (flashlight, comfortable sports shoes, maps), on the other hand, attributes indicating office work infiltrating the field (notebooks, sheets of paper, writing materials). Moreover, showing this physical creation, according to the respondents, was indicative of professionalism (a conviction that an effective probation officer, who is part of the supervised urban tissue, does not stand out, does not display inadequate formalism, thus becoming a 'transparent participant in reality,' and has all the essential gear).

N1: Well, my basic tool, apart from my pen and my legs, is unfortunately my phone. I have an app which scans documents (...). Phone, scanner, and that's it. I have no other inner resources. I scan documents, yes.,

N2: A flashlight is more of a gadget, but sometimes the light doesn't work.

N3: My car is the tool of my profession. It is something ... without which this job is difficult, and I do realise that my colleagues don't use cars. But I find it useful.

The researchers believe that each visit in the field is a type of trip or more accurately - a journey, which requires adequate luggage. Interpretation and a sense of the city shaped the construction of one's image while the choice of objects was indicated and justified through experiencing new places assigned to the supervised area. Interestingly, all respondents declared that they organized the materials themselves based on experience, which was connected with the specificity of particular areas of the city. They did not seek advice from older 
colleagues but worked out certain patterns of conduct, tactics, and a selection of aids, based on learning and understanding the 'demands of the area.'

Another aspect connected with the physical sphere of the city is based on creating 'personal' topographic maps. Probation officers who become familiar with a given area domesticate it, thus making the space less dangerous (in their view), as well as more accessible, practical, 'less time consuming,' and predictable. While accompanying them 'on their way' the researchers discovered many 'unofficial' routes - shortcuts connecting two areas (photo 1, 2, 3, 4), known only to local residents and to probation officers, who became part of the community through participation.
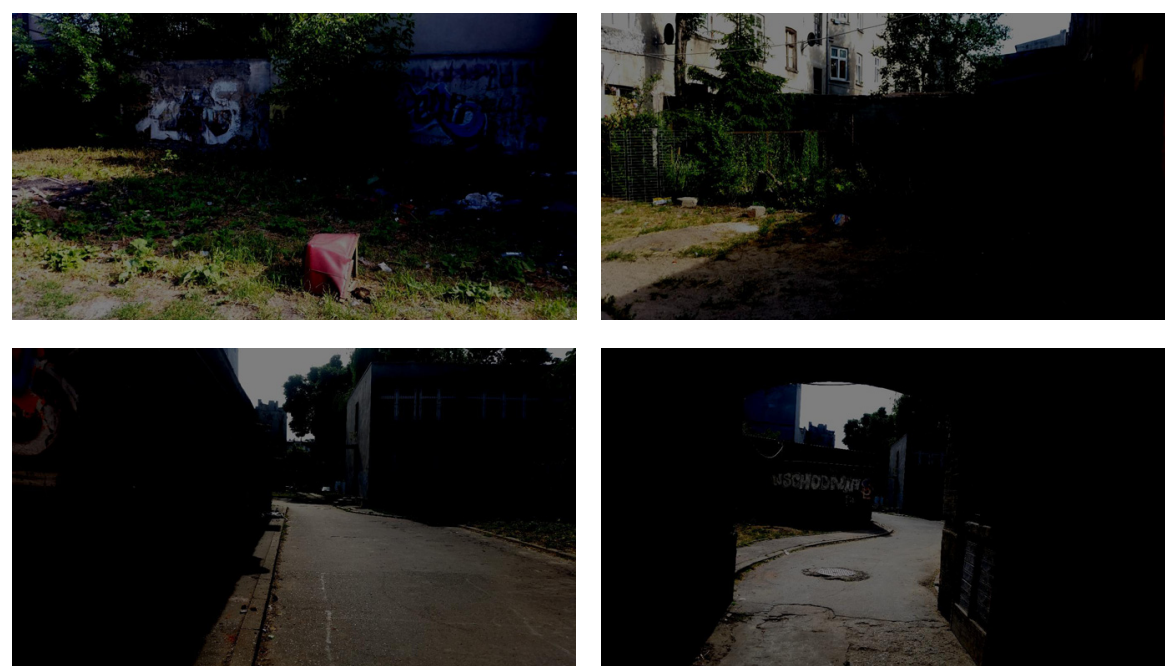

Photographs 1, 2, 3, 4. Fragments of an inner route located between the two main streets in the city centre. The so called 'passage' surrounded by walls and tenement houses. There are two main exits in the gates of the tenement houses. Photographs 1, 2 and 3 (successive elements of the inner route) and photograph 4 - a gate leading to the main street.

Interestingly, these labyrinthine passages create an impression of non-public spaces, seldom visited by larger groups of people (they are usually located in yards, hidden, shaded, similar to back streets). However, the respondents declared extensive knowledge of the area (resulting from their work experience), and a sense of security connected with this fact. The quick, confident, and dynamic presentation of the 'labyrinths' turned the probation officers into guides, perfectly familiar with the organization of life of the district's residents, and into 
experts who could predict and indicate threats and 'escape routes.' Their justification for using this passage was usually that it 'saves time.' According to the respondents, the shortcuts make their work more efficient (enabling them to visit more families in one day, and to conduct reconnaissance, e.g. a light turned on or an open window seen from the yard could be a signal that the ward is home, and that the visit will take place). This data revealed itself along the way. It was not elicited by questions. Individual elements of the space provoked the respondents to specific behaviour (gestures, glances, changing directions). These in turn, under the watchful eyes of the researchers, were transformed into supplementary questions, aimed at explaining the motivation, modes of perception, feeling etc. A common experience of the route allowed one to observe specifically delimited maps of the city, nearly inaccessible to 'typical residents of Lodz.' However, these maps do not possess a symbolic character. They are determined by infrastructure, buildings, clearly delineated by fences, gates, as well as graffiti, which identifies the district with e.g. the fans of a specific sports club.
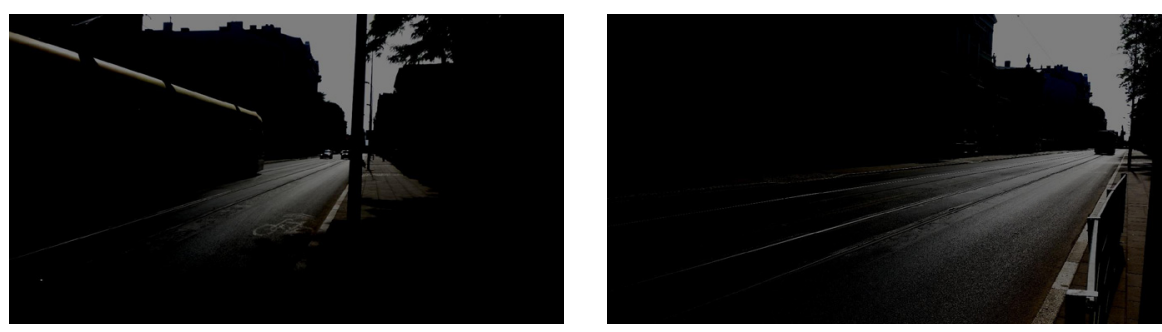

Photograph 5, 6 - a fragment of the main street, approximately 500 metres away from the passage. A busy city centre with polyclinics, urban transport, courts, numerous shops, car parks, schools and other public buildings.

An additional important element of 'personal' topographic maps are 'nodal points.' While visiting their wards probation officers meet their neighbours, caretakers, employees of local shops and institutions. Establishing such relationships helps in formal work, through extending the network of potential informers, and fosters the development of practical strategies of 'being' in the field. An example of this can be the knowledge of closely located polyclinics, schools, culture centres, local cafes, libraries, i.e. places where probation officers, owing to the kindness of the employees, can use the toilet, get warm, fill out a document, eat a meal or leave the car at a free car park. The officer's office (administrative work), as well as a number of basic needs, require the designa- 
tion of such 'nodal points.' It should be noted that revisited places located in the city space acquire different individualised meanings and functions for the probation officers.

N4: At the nurse's, the medical centre. I can go to any school, there are several schools here. (...) There are several schools, so I go to a school during its working hours, till $5 \mathrm{pm}$. But I'm still here after $5 \mathrm{pm}$. During the summer you can go to a hidden café in Plac Wolnosci. Very well hidden. It's a great place, you can sit down, fill out documents, use the toilet, it's great.

N5: Well, today I had this idea that I would leave the car at a friendly school, and make the rounds. Sometimes I arrive after lunch, and then I can't use the school car park, which is a form of courtesy for me.

Probation officers balance between extremely different areas of the city, crossing boundaries in a physical and symbolic sense, to finally become living carriers of change in the urban tissue. Their 'personal' topographic maps, apart from designated routes, directions of movement, and nodal points also have perpetuated 'documents of change.' Interestingly, these often had a personal dimension (stories from the individual point of view or about specific people). On their topographic maps probation officers perpetuated individual biographies which are inscribed into the city, becoming a testimony of human dilemmas and experience.

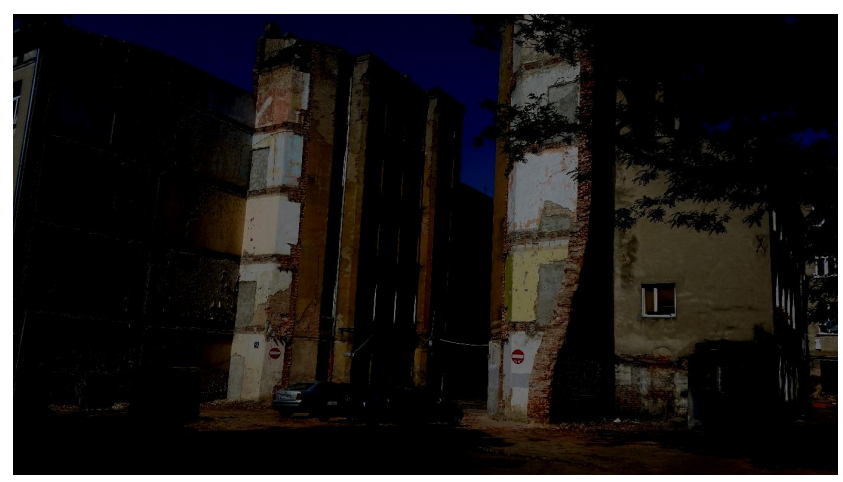

Photograph 7 - one of the tenement houses devastated and demolished as a result of a fire. The remnants of the walls are surrounded by buildings inhabited by supervised families. During the walk the probation officer gave a detailed account of the people involved in the fire. While she was talking a bystander joined the walk. He listened with interest and added his remarks. At that point the interview became a live interaction between the place, the respondent, the researchers, and the local community. 
N4: The tenement house was severely damaged by the fire. First, the entire front was evacuated, but when it was demolished, maybe these walls are solid. These flats are standing, and the people are waiting for new accommodation. New places were assigned to them, but they have to wait because of renovation. But this can collapse at any time. It was damaged during the demolition. And the fire, the extinguishing, the water. It looks completely different. Yes, I remember. Sir [to bystander], tell us about it, you lived in this place and you saw the fire.

Bystander: I saw them pulling the people out, but the fire was mainly upstairs. Only the lower flats didn't burn. You can see that they aren't sooty. They were only flooded, including the ceilings, and the people were evacuated. And this house, because the ceiling was made of wood, and they could only take it apart. They left the side tenements, because they are attached to these houses. And if they demolished them it would have weakened the other houses. It's not easy to find a way out.

N4: It's not, but they had to evacuate the other people, right?

B: Yes, I think so. Hardly anyone lives there, you're right.

N4: But the fire that was on the balcony, these people were burnt to death, right?

B: I think three people were killed, because that was a flat of sorts. They used to build lofts that way.

N4: A loft, yes. And when they poured water on it the house was destroyed.

B: Yes, you're right. And then the fire-fighters came for the second time, because he set fire to it again.

N4: The same [person]. And the same person set fire, the one who lived at no. 18 . He started the fire, but people came out and ....

N4: I hear there's still someone like that.

While on duty the probation officers are witnesses and participants of the revitalisation processes introduced by the city. These projects are important not only from the point of view of their responsibilities (e.g. interrupted cooperation with families moved to other premises due to renovation). Probation officers who experienced such urban transformations and found themselves in renovated areas, enjoyed looking back at the images preserved in their memories (they told anecdotes about the places and the inhabitants, visualised the previous state of the buildings, told of directions of the introduced changes, and of the consequences for their professional responsibilities and - more broadly - for the life quality of the residents).

N4: During the last ten or fifteen years the changes were colossal, regarding infrastructure and the looks of the city. But I don't think that a lot has changed. 
Apart from the fact that it looks better, life isn't easier for the residents. It's a facade. It is prettier on the outside. We're just tenements painted on the outside. On the inside everything is the same. I think that not enough money is invested to make lives better.

Probation officers with knowledge concerning the planned changes in the city expressed their opinions on the direction of these developments. They called for pragmatism with regard to space suited to the possibilities of the recipients, i.e. the local community (neighbourhood). They showed the city as a creation which functions next to or in opposition to people, especially the beneficiaries of the officers' activities, as a result of bad decisions. Based on their experience they showed the superficiality of the changes, and the discrepancy between the ideas and the needs of the people. In their construction of 'personal' topographic maps they criticised misguided investments (those under way and those planned). During the walks they tried to provide a precise and detailed characteristic of the place, its ideas, purpose and roles, which it plays in the lives of residents. They told the history of the place, its role in culture and in creating ties, which would seemingly be incomprehensible to 'regular recipients and participants in the city.'

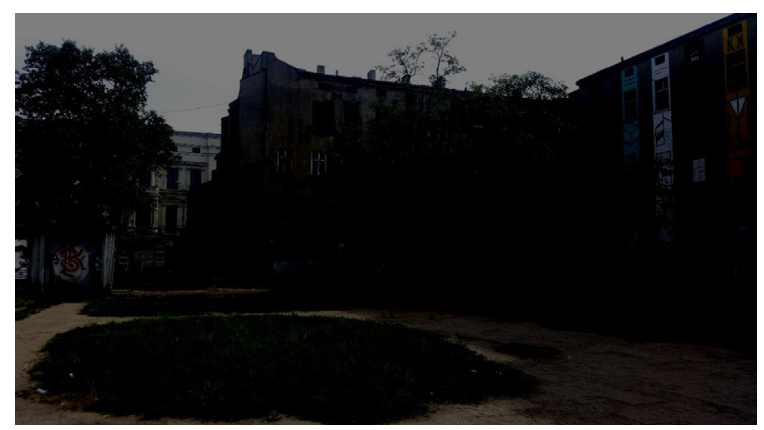

Photograph 8 - a square to which an officer devoted a large part of his story. The respondent believed that the square fulfilled its cultural and entertainment functions for the local society. It it used as a football field, a playground, as well as a meeting place for adults (e.g. in the summer it is used for picnics). The officer who described the functions of this space was opposed to its planned transformation (raising modern buildings and shops in place of the square). He clearly highlighted the significance of the area for the local community. During the walk the square was visited twice (as a result of crossing labyrinths and shortcuts mentioned before). During the walk one could see, experience, and get to know the place which is the arbitrary centre of a given community. 


\section{Transcendental and Symbolic Observations}

A key observation connected with the transcendental context of the field work of probation officers encompasses arbitrary defining of affiliation and non-physical establishing of boundaries between 'mine and not mine.' A district assigned to a probation officer by the court/institution acquired an additional dimension as a result of the walks. The researchers defined it as a symbolic appropriation of space. From the beginning the respondents saw themselves as hosts, who showed the guests around the place which is close and well known to them. Their first words often included a greeting or introduction, such as 'follow me.'

N4: We are in Wiekowa ${ }^{6}$ street. That side is mine. The one with the green [roof] up to Turkusowa street is all mine, and so is Okienna street, both on the left and the right side, up to Ziolowa street. Then there's Solankowa street - it's very little. One side belongs to me, the other to Izabela [another probation officer].

The attitude of the officers - sweeping gestures, indicating with their fingers or hands - seemed very important. In places considered as 'mine' one could see confidence and freedom of movement, dynamism, consciousness of direction etc. (despite the presence of an audience - residents, bystanders). This symbolic appropriation referred to being in a specific place and to the knowledge of that place. It also expressed a certain manner of management, administration, understanding and even deeper initiation. 'Mine' turned out to be something between ownership and belonging. This perception resulted in a clearly outlined difference between what was defined as space, and location. Yi-Fu Tuan (1987) once remarked that "humanized space is place." This remark is a very accurate metaphor which reflects the attitude of the respondents to selected fragments of the city. Seemingly neutral and indifferent space, through the professional work of probation officers, became a meaningful, understandable, and important place, which played an important role in building one's social and professional identity.

Determining what is 'mine and alien' was strongly connected with building symbolic boundaries and divisions. Probation officers turn fragments of the city into their workplace. At the same time this city constitutes their informal living space. Field work in this sense paradoxically transforms into activity, which is strongly rooted in the private sphere. All the respondents found it difficult to indicate an unambiguous boundary between what is professional and

\footnotetext{
${ }^{6}$ Street names were changed in order to make the conversation more lively.
} 
what is private (i.e. to determine where professional space ends and the space of personal comfort begins). Although they were capable (in a physical and administrative sense) to indicate the area and district under their supervision (photograph 9), they were trying hard to determine where the boundary between the private and the professional sphere was, and which parts of the city were for entertainment, and which constituted their workplace. This was particularly difficult for probation officers, who supervised families living in the city centre, i.e. the tissue, which houses a large number of families in need of support, and which is also the cultural and entertainment centre of the agglomeration, in which the officers participated ${ }^{7}$.

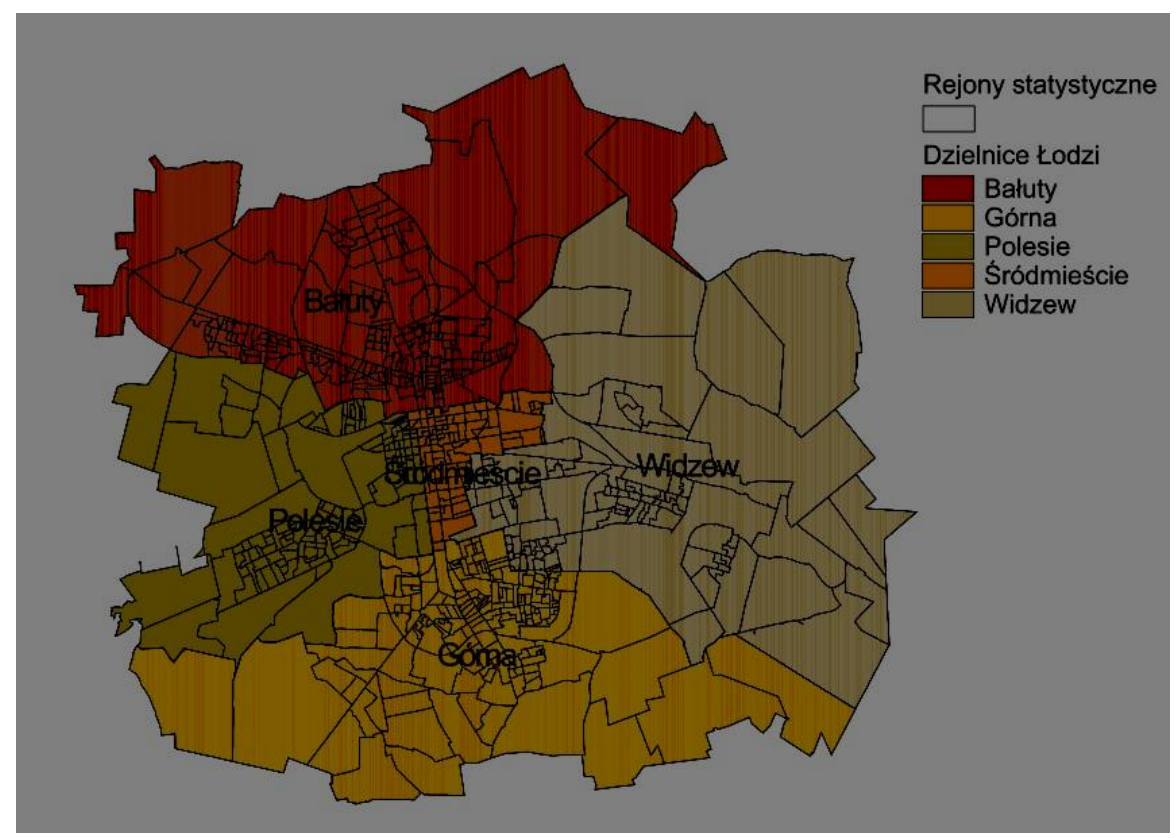

Photograph 9 - districts and statistical areas in Lodz; source: http://www.mapa. lodz.pl/mapa/atlas/P-24.pdf

This infiltration of private and professional spheres keeps the officers - according to them - in a state of constant, intensive vigilance (e.g. an expressed

${ }^{7}$ Distribution of so called poverty enclaves (division of the city by the occurrence of social dysfunctions) see: W. Warzywoda-Kruszyńska, B. Jankowski (2013). 
sense of being constantly observed in less formal social situations). Time off work becomes a form of developed self-control and specific self-discipline. Moreover, according to the respondents, a lack of clear-cut boundaries (their arbitrary and symbolic character), does not allow them to fully distance themselves from professional activities, and makes them think constantly about the problems of their wards, their actions, situation analysis etc.

Researcher: So [places where you spend your free time] are also far away from the areas you supervise?

N7: This guarantees greater emotional hygiene. I think it's important to set boundaries in everything, including this. This work infiltrates our lives, so it's worth setting up such sensible boundaries.

R: Is it possible?

N7: They're unconventional anyway. We try [...] Now I'm living over a dozen [kilometres from the city]. Back then [when the probation officer used to live closer to the city centre] my husband used to say: listen, if we lived in Lodz, as we did over ten years ago, you'd be at work all the time, right? So distance does create distance. [...]

R: Is there a specific street or point which determines the boundary between work and home?

N7: No, it's a mental boundary. It's when I drive home and think about what happened at work, during the day.

Ultimately, the distance and unconventionality of the probation officers' workplace may simultaneously influence and determine (e.g.) their preferred ways of spending free time (selection of leisure space).

R: When you're looking for a place to spend leisure time, is it far from the supervised area?

N7: This has changed a lot and it's still evolving. I think that now when I choose a place to spend my holidays, I choose the countryside, and it's quiet. I don't like people walking around. It's certainly not Leba or Wladyslawowo. I'd be happy to visit Gdansk, but I'd rather go to Kobyla Kepa, where it's quiet. I go out in the morning, I see birds and I'm delighted.

\section{Final Thoughts and Further Research Directions}

The key question, which the researchers asked in the course of analysing the collected material, related to the uncanny diversity in determining the scope and range of work of probation officers, as well as the unusual competence shaped in the course of grounding oneself in a 'personal city.' Paradoxically, the study 
provided more open and unresolved issues than answers. These issues drew the researchers' attention to the impossibility of determining what a place (a symbolic place with a special significance) is and what role it plays in creating its identity. The primary point of interest for the researchers is whether probation officers in urban space broaden the arm of the institution, or is the institution merely an element of constant work in the field?

Arguably, using mobile methods oriented towards experiencing and learning space made it possible to reach seldom discussed and explored aspects of probation officers' work. The collected material allowed the researchers to determine the role of the city in shaping the field work of probation officers. Although observations were based on the specific space of the city of Lodz, both, the suggested arrangement of the study and the conclusions can be adapted for other studies on the field work of probation officers (including those which transcend the borders of explored cities). The issue of constructing 'personal' topographic maps, both in a physical and in a symbolic dimension is of particular interest. Following the directions in the common experience of respondents and researchers helped to reachprobation officers' work contexts undiscovered in classic interviews. Being in a given space triggered developed stories, which refer directly to the experienced place, as well as deeper reflections on the wards' quality of life. Moreover, it needs to be stressed that the researchers abandoned observations of the relationship between probation officers and wards, focusing on the relationship between respondents and place instead. This perspective revealed a valuable voice concerning the socio-spatial contexts of work, significantly influencing the quality and organization of preventive, rehabilitation and support measures. The image of the city perpetuated by the respondents, especially their thoughts on the utility and purpose of space, the bond-creating role of places which seemingly require renovation, and the effects and scope of revitalisation is also significant. Since probation officers 'sink into' urban space so deeply, it appears that learning about their work through the 'urban lens' is the most effective path to understanding the professional world of this group.

\section{References}

Anderson, J. (2004). Talking Whilst Walking: A Geographical Archaeology of Knowledge. Area 36(3), pp. 254-261.

Bałandynowicz, A. (2009). Probacja - wielopasmowa teoria resocjalizacji z udziałem społeczeństwa. Probacja 1(09), pp. 11-49. 
Banks, M. (2009). Materiały wizualne w badaniach jakościowych. Warszawa: Państwowe Wydawnictwo Naukowe.

Becker, H. (1979). Do Photographs Tell the Truth? In: D. Thomas, R. Cook (ed.), Qualitative and Quantitative Methods in Evaluation Research ( pp. 99-117). London: SAGE Publication.

Becker, H. (1974). Photography and sociology. Studies in the Anthropology of Visual Communication (1), pp. 3-26.

Bourdieu, P. (1990). The Social Definition of Photograpfy. In: P. Bourdieu, L. Boltanski, R. Castel, J.C. Chamboredon, D. Schnapper (eds.), Photography. A middle-brow (pp. 73-98). Cambridge: Polity.

Collier, J., Collier, M. (1986). Principles of Visual Research. In: J. Collier, M. Collier (ed.), Visual Anthropology. Photography as a Research Method (pp. 161-173). Albuquergue: University of Mexico Press.

Cywiński, A. (2018). Wzajemne społeczne reprezentacje zawodowych kuratorów sadowych do spraw dorostych i ich podopiecznych. Kraków: Oficyna Wydawnicza "Impuls".

Edensor, T. (2010). Walking in Rhythms: Place, Regulation, Style and the Flow of Experience. Visual Studies 25(1), pp. 69-79.

Emmison, M., Smith, P. (2000). Current Trends in Visual Research: a Conceptual Revwiew. Researching the Visual. London: SAGE.

Gawęcka, M. (2009). Resocjalizacja w środowisku otwartym. Koincydencja probacji i pracy socjalnej. Probacja (3-4), pp. 54-70.

Gogacz, K. (2012). Różnicowanie oddziaływań resocjalizacyjnych społecznych kuratorów sądowych a efektywność dozorów probacyjnych. Radom: Wydawnictwo Wyższej Szkoły Handlowej w Radomiu.

Górnicka, B. (2016). Współpraca z podopiecznymi, ich rodziną i szkołą w opiniach rodzinnych kuratorów sądowych. Resocjalizacja Polska 12, pp. 217-237.

Grady, J. (2008). Visual Research at the Crossroads. Qualitative Social Research 9(3). DOI: http://dx.doi.org/10.17169/fqs-9.3.1173.

Harper, D. (1987). The Visual Ethnographic Narrative. Visual Anthropology 1(1), pp. 1-19.

Heine, M. (2008). Funkcjonowanie kurateli sądowej w nowych realiach normatywnych. In: M. Konopczyński, B. Nowak (eds.), Resocjalizacja - ciągłość i zmiana (pp. 117-129) Warszawa: Pedagogium.

Hofoka, M., Woo, Y., Hsieh, M., Wormer, J., Stohr, M., Hemmens, C. (2017). What Legally Prescribed Functions Tell Us: Role Differences between Adult and Juvenile Probation Officers. Federal Probation 81(3), pp. 32-47. 
Jadach, K. (2011). Praca kuratora sadowego w sprawach rodzinnych nieletnich $i$ karnych. Poznań: Wydawnictwo Uniwersytetu Adama Mickiewicza.

Janus-Dębska, A., Gronkiewicz-Ostaszewska, M. (2016). Bezpieczeństwo kuratorów sądowych w świetle badania ankietowego (pp. 53-83). Warszawa: Instytut Wymiaru Sprawiedliwości.

Lashua, B. D. (2006). "Just Another Native?" Soundscapes, Chorasters, and Borderlands in Edmonton, Alberta, Canada. Cultural Studies. Critical Methodologies, 6(3), pp. 391-410.

Majer, A. (2015). Mikropolis. Socjologia miasta osobistego. Warszawa: Wydawnictwo Uniwersytetu Łódzkiego.

Majer, A. (2016). Miasto w osobistym wymiarze. Studia Miejskie 21, pp. 9-28.

Marynowicz-Hetka, E. (2010). Kategoria pomocy w rozwoju - analiza z punktu widzenia pedagogiki społecznej. In: K. Baranowicz, A. Sobczak, M. Znajmiecka-Sikora (eds.), Rozwój i jego wspieranie w perspektywie nauk o człowieku- teoria i rozwiazania praktyczne (pp. 9-19). Łódź: Wydawnictwo Uniwersytetu Łódzkiego.

Murray, L. (2012). Patrząc na i patrząc wstecz: wizualizacja w badaniach nad przemieszczaniem się (tłum. A. Dzik). In: M. Boguni-Borowska, P. Sztompka (eds.), Fotospoteczeństwo. Antologia tekstów z socjologii wizualnej (pp. 780-804). Kraków: Wydawnictwo Znak.

Myers, M. (2010). Walk with Me, Talk with Me: the Art of Conversive Wayfinding, Visual Studies 26(1), pp. 50-68.

Nowak, M. (2009/2010). Uwarunkowania skutecznej pracy kuratorskiej. Szkice Podlaskie 17(18), pp. 291-299.

O’Neill, M., Perivolaris, J. (2014). A Sense of Belonging: Walking with Thaer through migration, memories and space in Crossings. Journal of migration and culture (5), pp. $327-338$.

O’Neill M., Hubbard, P. (2010). Walking, Sensing, Belonging: Ethno-Mimesis as Performative Praxis. Visual Studies 25(1), pp. 46-58.

O’Neill, M. (2014). Participatory Biographies: Walking, Sensing, Belonging, In: M. O’Neill, B. Roberts, A. Sparkes (eds.), Advances in Biographical Methods: creative applications (pp. 73-89). London: Routledge.

Pink, S. (2007). Doing Visual Ethnography: Images, Media and Representation Research. Kraków: Copyright for Polish Translation and Edition by Wydawnictwo Uniwersytetu Jagiellońskiego.

Sheller, M., Urry, J. (2006). The New Mobilities Paradigm. Environment and Planning, Economy and Space (38), pp. 207-226. 
Short, J. R. (2006). Urban Theory: A Critical Assessment. New York: Palgrave Macmillan.

Skowroński, Ł. (2016). Wypalenie zawodowe sądowych kuratorów zawodowych wykonujących orzeczenia w sprawach karnych i rodzinnych. Resocjalizacja Polska 11, pp. 185-209.

Stasiak, K., Jedynak, T. (2014). Zarys metodyki pracy kuratora sqdowego. Warszawa: LexisNexis.

Stasiak, K. (2010). Ewolucja systemu kurateli sądowej w Polsce w latach 1919-2009-kamienie milowe. In: K. Stasiak, Ł. Wirkus, P. Kozłowski, T. Jedynak (eds.), Dziewięćdziesięciolecie kurateli sądowej w Polsce Historia-Teraźniejszość-Przyszłość (pp. 45-71). Kraków: Oficyna Wydawnicza „Impuls”.

Viglione, J., Rudes, D.S.,Taxman, F. (2017). Probation Oficer Use of Client-Centered Communication Strategies in Adult Probation Settings. Journal of Offender Rehabilitation 56(1), pp. 38-60.

Wagner, J. (1979). Images of Information. Still Photography in the Social Science. Beverly Hills: Sage.

Warzywoda-Kruszyńska, W., Jankowski, B. (2013). Ciagłość i zmiana w łódzkich enklawach biedy. Łódź: Wydawnictwo Uniwersytetu Łódzkiego.

Węgliński, A. (2015) . Zasoby osobiste społecznych kuratorów sądowych niezbędne w przezwyciężaniu zaburzeń w przystosowaniu dozorowanych z problemem alkoholowym. In: A. Bałandynowicz, E. Jówko, K. Marciniak-Paprocka (eds.), Edukacja inkluzyjna. Konteksty indywidualistyczne, wspólnotowe i interpersonalne, cz. II (pp. 343-364). Siedlce: Wydawnictwo Uniwersytetu Przyrodniczo-Humanistycznego.

Wirkus, Ł. (2015). Stres w pracy kuratora sądowego. Kraków: Oficyna Wydawnicza „Impuls".

Wojtera, E. (2012). Bezpieczeństwo pracy kuratora sądowego w ujęciu uniwersalnym i interdyscyplinarnym. Resocjalizacja Polska, (3), pp. 187-212.

Yi-Fu, T. (1987). Przestrzeń i miejsce. Warszawa: Państwowy Instytut Wydawniczy.

Youngs, D., Canter, D., Carthy, N. (2014). The Offender's Narrative: Unresolved Dissonance in Life as a Film (LAAF) Responses. Legal and Criminological Psychology, DOI:10.1111/lcrp.1207.

\section{Akty prawne:}

Probation Officer Act of 27 July 2001) determining the work structure of probation officers, there is also the Regulation of the Minister of Justice of 26 February 2013, on the me- 
thod of exercising powers and duties probation officers in criminal enforcement cases (Journal of Laws from 2013, item 335).

Regulation of the Minister of Justice of 12 June 2003, on the detailed method of exercising powers and duties of probation officers (Journal of Laws 2003, No. 112, item 1064). 